MONIKA NOWAKOWSKA* - LUBLIN

ANNA PAWŁOWSKA** - LUBLIN

\title{
BIBLIOTEKA INSTYTUTU HISTORII KATOLICKIEGO UNIWERSYTETU LUBELSKIEGO JANA PAWLA II
}

\section{Historia}

„Badając przeszłość patrzymy ku przyszłości”” - te słowa Kardynała Stefana Wyszyńskiego mogą stanowić motto odzwierciedlające pracę historyka, zaś miejscem ułatwiającym trud tej pracy jest biblioteka. Prezentowany artykuł jest próbą zebrania w jedną całość zagadnień związanych z dziejami Biblioteki Instytutu Historii, jej funkcją oraz kształtowaniem się zawartości zasobu. Do opracowania posłużyły protokoły z posiedzeń Rady Wydziału Nauk Humanistycznych, sprawozdania statystyczne i korespondencja Zakładu Historii oraz akta osobowe. Niezwykle pomocne okazały się relacje ustne pracowników oraz wspomnienia wydane drukiem.

Biblioteka Instytutu Historii służy zarówno studentom, jak i kadrze naukowej jednego z najstarszych kierunków KUL ${ }^{2}$. Program studiów historycznych wymaga ciągłego kontaktu z literaturą i różnego typu źródłami. Możemy zaryzykować stwierdzenie, że dla wielu pracowników naukowych doskonalących swój warsztat - biblioteka była drugim domem. Biblioteka była też miejscem gdzie studencka brać dyskutowała np. na temat zajęć, wykładowców czy bieżących wydarzeń. Problemy lokalowe oraz duże rzesze studiującej młodzieży prowadziły niejednokrotnie do tego, że zajęcia lub zaliczenia ćwiczeń odbywały się w czytelni, a nawet w magazynowych piwnicach. Te ostatnie budziły dodatkowe emocje.

\footnotetext{
* Monika Nowakowska - dr historii, bibliotekarz w Bibliotece Instytutu Ekonomii KUL, e-mail: mnowak@kul.lublin.pl

** Anna Pawłowska - mgr historii, bibliotekarz w Bibliotece Instytutu Historii KUL, e-mail: anikata@kul.lublin.pl

${ }^{1} \mathrm{~S}$. Wyszyński, Kazanie i przemówienie na uroczystości milenijne na KUL-u, „Zeszyty Naukowe Katolickiego Uniwersytetu Lubelskiego", 4 (1966) s. 81.

${ }^{2}$ W 1918 r. w ramach Wydziału Nauk Humanistycznych powołano do życia tzw. grupę historyczną. Zob. R. Bender, Historia na Wydziale Nauk Humanistycznych KUL (1918-1966), „,Roczniki Humanistyczne", 18 (1970) z. 4, s. 141.
} 
Jako datę powołania biblioteki historycznej źródła podają rok 1918 lub 1919³. Początkowo biblioteka nosiła nazwę Biblioteki Seminarium Historycznego. W 1946 r. została utworzona z inicjatywy prof. Andrzeja Wojtkowskiego (ówczesnego dyrektora Biblioteki Uniwersyteckiej KUL) Biblioteka Zakładu Historii Kultury ${ }^{4}$. W związku z tym, biblioteka historyczna funkcjonowała od 1946 r. do 1999 r. jako Biblioteka Zakładu Historii i Historii Kultury. Wraz z podjęciem uchwały Senatu Akademickiego z dnia 10 grudnia 1999 r. Sekcja Historii zmieniła nazwę na Instytut Historii, a biblioteka została przemianowana na Bibliotekę Instytutu Historii.

Biblioteka seminaryjna funkcjonowała w oparciu o Statut KUL, zatwierdzony w 1928 r. Pod względem organizacyjnym biblioteka podlegała kierownikowi Sekcji Historii. Po drugiej wojnie światowej Biblioteka Sekcji (Zakładu) Historii zależna była, jak i w okresie wcześniejszym, od kierownika Sekcji Historii. Dopiero od 1949 r. Komisja Biblioteczna Biblioteki Głównej objęła ją swoim nadzorem 5 . Od 1 grudnia 1969 r. wprowadzono w życie Regulamin sieci bibliotek $K U L^{6}$, który dawał bibliotekom zakładowym dużą samodzielność. Zadaniem bibliotek było organizowanie warsztatu pracy naukowej i dydaktycznej w zakresie określonej specjalizacji. Podlegały one kierownikowi zakładu, który był odpowiedzialny za księgozbiór, jego opracowanie i udostępnianie oraz dobór kadry. Kierownik biblioteki został zobowiązany do przesyłania sprawozdań oraz kart do katalogu centralnego do Biblioteki Głównej ${ }^{7}$. Kolejne regulacje prawne dotyczące bibliotek przyniósł Statut KUL z dnia 17 marca 2006 r. ${ }^{8}$ oraz Regulamin Biblioteki Uniwersyteckiej z dnia 25 kwietnia 2007 r. ${ }^{9}$ Na jego podstawie Biblioteka Instytutu Historii jest jedną z 24 bibliotek specjalistycznych Katolickiego Uniwersytetu Lubelskiego Jana Pawła II, organizacyjnie powiązanych z Biblioteką Uniwersytecką KUL. Jej celem jest organizowanie warsztatu pracy dydaktycznej dla potrzeb jednostki organizacyjnej Uniwersytetu, przy której została powołana. Nadzór merytoryczny nad biblioteką sprawuje dyrektor Instytutu Historii ${ }^{10}$.

${ }^{3}$ Archiwum Uniwersyteckie Katolickiego Uniwersytetu Lubelskiego Jana Pawła II (dalej: AU KUL), Biblioteka Uniwersytecka, Sprawozdania kierowników bibliotek seminaryjnych 1922-1939, Pismo Dziekana prof. Leona Białkowskiego do Rektora z dnia 22. 06. 1932 r.; Biblioteka Seminarium Historycznego. Kwestionariusz nr 1; AU KUL, Kancelaria Rektorska. Biblioteki Zakładowe 1946-1950; Kwestionariusz statystyczno-sprawozdawczy do Ministerstwa Oświaty za rok 1950. Zakład Historii.

${ }^{4}$ AU KUL, Kancelaria Rektorska. Kwestionariusz sprawozdawczo-statystyczny za rok 1951 do Ministerstwa Kultury i Sztuki. Zakład Historii Kultury Polskiej.

${ }^{5}$ B. Koszałka, Biblioteki zaktadowe Katolickiego Uniwersytetu Lubelskiego, „Archiwa Biblioteki i Muzea Kościelne”, 23 (1971) s. 179.

${ }^{6}$ AU KUL, Kancelaria Rektorska. Biblioteka Uniwersytecka. Korespondencja. Sprawy ogólne 1969-1984; Regulamin Sieci Bibliotek Katolickiego Uniwersytetu Lubelskiego w dn. 10.11.1969 r.

${ }^{7}$ Tamże. Rozdział I Uwagi ogólne, pkt 3. II Organizacja pkt 12, 16.

${ }^{8}$ Statut Katolickiego Uniwersytetu Lubelskiego Jana Pawła II z dnia 17 marca 2006 r.

${ }^{9}$ Regulamin Biblioteki Uniwersyteckiej Katolickiego Uniwersytetu Lubelskiego Jana Pawła II z 25 kwietnia $2007 \mathrm{r}$.

${ }^{10}$ Tamże, § 4-5. 


\section{Pracownicy}

W początkowym okresie istnienia biblioteki seminaryjnej, nie było etatowego pracownika bibliotecznego. Księgozbiór pozostawał pod nadzorem profesorów i studentów udostępniających książki. Wiadomo, że w latach 30-tych opiekunem biblioteki był mieszkający w gmachu KUL prof. Aleksander Kossowski - wykładowca historii nowożytnej. Każdy dyżurny student zgłaszał się do profesora po klucz ${ }^{11}$.

W połowie lat 50. XX wieku dr Jerzy Łukaszewski prowadził biuro Zakładu. Do jego obowiązków należał zakup książek i materiałów biurowych ${ }^{12}$. Ogrom pracy wymagał zaangażowania i odpowiedniej ilości fachowców. Organizowano więc w Bibliotece Głównej KUL kursy biblioteczne dla studentów. Najprawdopodobniej pierwszy kurs (40 godzin) odbył się w miesiącach listopad-grudzień 1952 r. ${ }^{13}$ Spośród asystentów odpowiednie kwalifikacje do pracy w bibliotece posiadała Ewa Jabłońska-Deptuła, gdyż od 1 lutego 1950 r. do 31 maja 1951 r. odbywała praktykę w Bibliotece Narodowej w Warszawie ${ }^{14}$.

Pierwszym bibliotekarzem zatrudnionym na stałe w Bibliotece Zakładu Historii był mgr Stanisław Olczak. Funkcję tę pełnił od 1 października 1966 do końca grudnia 1973 r. Wiadomo, że w pracy pomagali mu również asystenci i stypendyści. Od grudnia 1970 r. do grudnia 1974 r. było po dwóch asystentów i stypendystów.

Od 1 stycznia 1974 r. na stanowisku bibliotekarza w Zakładzie Historii została zatrudniona mgr Elżbieta Janicka-Olczak ${ }^{15}$. Posiadała ona odpowiednie przygotowanie biblioteczne (słuchaczka Dwuletniego Międzywydziałowego Kursu Bibliotekarskiego). Oprócz podstawowych zadań w bibliotece: gromadzenia, opracowywania i udostępniania, w wakacje prowadziła praktyki w zakresie bibliotekarstwa ${ }^{16}$. W latach 80 . i 90 . XX wieku liczba zatrudnionych asystentów

${ }^{11}$ J. Wojtiszek, Wspomnienia z lat studiów, w: Katolicki Uniwersytet Lubelski w latach 19251939 we wspomnieniach swoich pracowników i studentów, wstęp i red. Grażyna Karolewicz, Lublin 1989 , s. 245-246.

${ }^{12}$ Jerzy Łukaszewski - ur. 1924 r. w Terebieżowie. Stopień doktora prawa uzyskał na Wydziale Prawno-Ekonomicznym Uniwersytetu w Poznaniu. Zatrudniony na Katolickim Uniwersytecie Lubelskim w latach 1951-1960. Prowadził zajęcia na sekcjach: historii, filologii germańskiej, filologii polskiej. Specjalizował się w historii politycznej i dyplomatycznej czasów nowożytnych i najnowszych. AU KUL, Referat Personalny, Akta osobowe pracowników, Łukaszewski Jerzy, sygn. A 384.

${ }_{13}$ AU KUL, Kancelaria Rektorska. Biblioteka Uniwersytecka 1952-1969; Sprawozdanie z kursu bibliotekarskiego dla stypendystów pracujących w Bibliotekach Zakładowych KUL w roku 1952/53.

${ }^{14}$ Ewa Maria Jabłońska-Deptuła (1931-2008) - absolwentka historii Uniwersytetu Warszawskiego. 1 października 1957 r. została zatrudniona na stanowisku asystenta w Zakładzie Historii. AU KUL, Referat Personalny, Akta osobowe pracowników, Jabłońska-Deptuła Ewa, sygn. A582.

${ }^{15}$ AU KUL, Referat Personalny, Akta osobowe pracowników, Elżbieta Janicka-Olczak, sygn. A 999.

${ }^{16}$ W styczniu 1984 r. Rada Wydziału Nauk Humanistycznych (dalej: RWNH) wyraziła zgodę na wprowadzenie na Sekcji Historii specjalizacji bibliotecznej. Jednakże ze względu na problemy zdrowotne wykładowców, zajęcia dla studentów (nie tylko historii) na specjalizacji rozpoczęły się 
w bibliotece wahała się od 3 do 6 , a liczba stypendystów wynosiła od 2 do $4^{17}$. W latach 2004-2012 liczba stypendystów pomagających w bibliotece wynosiła od 7 (gdy istniały dwie czytelnie) do 3 dyżurnych (w roku akademickim 2011/2012). Ich zadaniem była obsługa czytelników. Pani mgr Elżbieta Janicka-Olczak kierowała biblioteką Instytutu Historii do momentu przejścia na emeryturę, tj. do 31. 12. 2005 r. W październiku 2004 r. w Bibliotece Instytutu Historii zostały zatrudnione: mgr Monika Nowakowska i mgr Anna Pawłowska. Obydwie ukończyły dwuletnią specjalizację biblioteczną (w tym odbyły praktyki specjalistyczne w bibliotekach naukowych).

\section{Księgozbiór}

Na obecny zasób Biblioteki Instytutu Historii składają się księgozbiory Biblioteki Zakładu Historii, Biblioteki Zakładu Historii Kultury oraz dawnej Biblioteki Koła Naukowego Historyków. W 1946 r. z dubletów Biblioteki Uniwersyteckiej powstała Biblioteka Zakładu Historii Kultury licząca 750 tomów ${ }^{18}$. Na podstawie rocznego sprawozdania Seminarium Historii Kultury Polskiej wiadomo, że liczba książek w 1948 r. (stan na dzień 1 września) wzrosła do 905 (1.071 woluminów). $\mathrm{Na}$ koniec roku akademickiego (stan na 15 czerwca) biblioteka liczyła 957 dzieł w 1149 woluminach ${ }^{19}$. W 1949 r. w inwentarzu biblioteki wpisanych było 1096 książek, a rok później liczba ta wzrosła prawie o $20 \%$ - do 1.363 pozycji ${ }^{20}$. W świetle sprawozdania z roku akademickiego 1951/1952 Biblioteka Zakładu Historii Kultury posiadała na swoim stanie już 2.300 woluminów ${ }^{21}$. Obecnie inwentarz Biblioteki Historii Kultury (oznaczony literą K) notuje 2.500 woluminów, w tym 479 wydań XIX-wiecznych.

w 1985 r. AU KUL, Wydział Nauk Humanistycznych, Księga Protokołów RWNH, Protokół z posiedzenia RWNH z dn. 18.01.1984 r. oraz Protokół z posiedzenia RWNH z dn. 20.02.1985 r.

${ }^{17}$ Od 1 października 1993 r. stypendyści-doktoranci (asystenci) byli zatrudnieni w bibliotece w wymiarze 1/2 etatu (20 godzin tygodniowo). Zaś stypendystami zakładowymi, rekrutującymi się spośród studentów magisterskich studiów dziennych, mogli być przede wszystkim osoby, które nie pobierały stypendium socjalnego. AU KUL, Senacka Komisja Młodzieżowo-Stypendialna, Wykazy stypendium naukowo-zakładowych. Wyciąg z protokołu nr 511 z posiedzenia Senatu Akademickiego KUL w dn. 15. 05. 1993 r. W dniu 8 kwietnia 1995 roku Senat Akademicki KUL postanowił przekształcić dotychczasowe stypendia zakładowe w stypendia naukowo-zakładowe. Wysokość stypendium ustalono na kwotę $110 \mathrm{zł} \mathrm{miesięcznie.} \mathrm{Studenci} \mathrm{ubiegający} \mathrm{się} \mathrm{o} \mathrm{te} \mathrm{stypendia}$ musieli spełnić następujące warunki: zaliczyć sesję egzaminacyjną ze średnią ocen powyżej 3,6 oraz uzyskać pozytywną opinię Kierownika Zakładu i Dziekana Wydziału. AU KUL, Senacka Komisja Młodzieżowo-Stypendialna, Studenckie Stypendia Socjalne. Stypendia naukowo-zakładowe 19941995. Wyciąg z protokołu nr 529 z posiedzenia Senatu Akademickiego KUL w dn. 08. 04. 1995 r.

${ }^{18}$ Skład osobowy. Spis wykładów i instytucji Katolickiego Uniwersytetu Lubelskiego w roku akademickim 1946/1947 oraz sprawozdania za lata ubiegłe, Lublin 1947, s. 48.

${ }^{19}$ AU KUL, Wydział Nauk Humanistycznych. Zakład Historii. Roczne sprawozdanie Seminarium Historii Kultury Polskiej, Sygn.V 421

${ }^{20}$ AU KUL, Kancelaria Rektorska. Biblioteki Zakładowe 1946-1950; Kwestionariusz statystyczno-sprawozdawczy do Ministerstwa Oświaty za rok 1950.

${ }^{21}$ AU KUL, Wydział Nauk Humanistycznych. Zakład Historii. Sygn.V 421 
Na księgozbiór Biblioteki Instytutu Historii składa się również zasób książek i czasopism Koła Historyków Studentów KUL, założonego 31 maja 1919 $\mathrm{roku}^{22}$. W latach 40-tych liczba książek gromadzona przez Koło, liczyła około 350 woluminów. Studenci prenumerowali czasopisma m.in. „Przegląd Historyczny”, „Kwartalnik Historyczny”23. Osobą odpowiedzialną za nadzór nad istniejącym księgozbiorem sprawował bibliotekarz Koła, wybierany na zebraniach Zarządu.

W styczniu 1971 r. w Bibliotece Zakładów Historii i Historii Kultury druków zwartych było 13.786 woluminów, a czasopism - 1.764 woluminy. Zbiory specjalne liczyły 3.668, w tym: starodruki, mapy, rękopisy, mikrofilmy, tablice paleograficzne. Dziesięć lat później druki zwarte stanowiły 17.158 woluminów (przyrost o około 24\%), a czasopisma 2.416 woluminów (wzrost o około $36 \%$ ), natomiast zbiory specjalne liczyły 4.286 jednostek (wzrost wynikał przede wszystkim z napływu prac magisterskich). Na koniec 1990 r. stan księgozbioru wynosił odpowiednio: druki zwarte -22.433 woluminy, czasopisma -2.775 woluminów, zbiory specjalne -4.556 jednostek. Obecnie (stan na 30. 06. 2012 r.) inwentarze biblioteczne notują 33.878 woluminów, 1.313 zbiorów specjalnych (głównie tablice paleograficzne i mapy).

W 2009 r. wszystkie mikrofilmy znajdujące się na stanie biblioteki zostały przekazane do Ośrodka Archiwa, Biblioteki i Muzea Kościelne w celu opracowania i sporządzenia inwentarza. Przyrost liczebności księgozbioru w latach 19712011 przedstawia poniższy wykres.

Wykres nr 1. Liczba woluminów księgozbioru Biblioteki Instytutu Historii KUL w latach 1971-2011/ The number of the volumes in the Library of the Institute of History of KUL in the years 1971-2011.

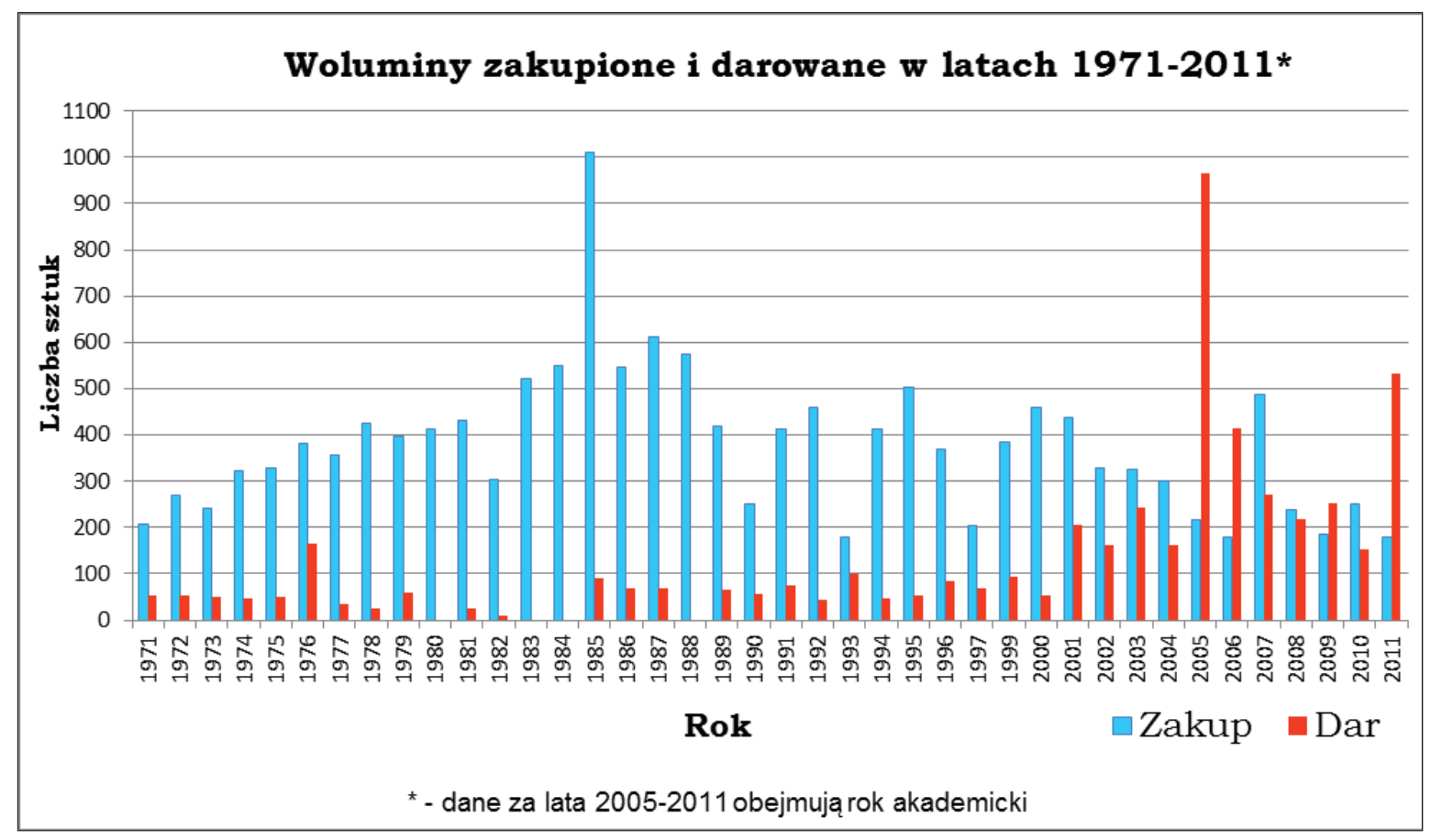

${ }^{22}$ Koło Naukowe Historyków Studentów KUL 1919-2004 - księga jubileuszowa, red. E.M. Ziółek, Lublin 2004, s. 20-21;

${ }^{23}$ Tamże, s. 83- 84. 
Na podstawie wykresu można stwierdzić, że większość nabytków biblioteki pochodzi z zakupów, niemniej jednak w ostatnich latach (2006-2011) przeważały książki podarowane bibliotece. Są to przede wszystkim darowizny przekazane przez prof. Zygmunta Sułowskiego ${ }^{24}$, prof. S. Litaka ${ }^{25}$. W listopadzie 2008 r. 80 woluminów (rosyjskojęzycznej literatury poświęconej dekabrystom) przekazała do biblioteki - prof. Wiktoria Śliwowska ${ }^{26}$. Wiosną 2009 r. za pośrednictwem Towarzystwa Świętego Pawła w Lublinie do biblioteki trafił księgozbiór ks. dr Stefana Mizery ${ }^{27}$. Dominowały w nim pozycje z zakresu historii gospodarczej, regionalnej oraz historii Kościoła.

Księgozbiór biblioteki powiększał się również dzięki ofiarodawcom instytucjonalnym. Były to: Ambasada Stanów Zjednoczonych [w Warszawie?], Polskie Towarzystwo Historyczne w Wielkiej Brytanii, Polskie Towarzystwo Historyczne w Londynie, Polski Instytut Historyczny w Rzymie, Polish Institute of Arts and Sciences of America, Polski Związek Akademików w Stanach Zjednoczonych, Szkoła Główna Gospodarstwa Wiejskiego, Archiwum Państwowe w Przemyślu, Polski Związek Wschodni, Instytut Europy Środkowo-Wschodniej, Instytut Pamięci Narodowej, Zakład Archeologii Uniwersytetu Marii Curie-Skłodowskiej. Ponadto Biblioteka Uniwersytecka KUL regularnie przekazuje książki i czasopisma będące jej dubletami.

Dokładny rozkład procentowy książek zakupionych i podarowanych Bibliotece Instytutu Historii przedstawia wykres nr 2.

${ }^{24}$ Zygmunt Sułowski (1920-1995) - historyk, mediewista, od 1951 r. związany z KUL; w latach 1957-1959 i 1966-1981 [daty?] prodziekan, a w latach 1974-1981 dziekan Wydziału Nauk Humanistycznych KUL; kierownik Katedry Nauk Pomocniczych i Metodologii Historii; badacz problematyki dziejów Słowiańszczyzny, historii Kościoła, demografii historycznej (biogram w : [autor, tytuł biogramu] „Roczniki Humanistyczne”, 35 (1987) z 2, s. 5-9).

${ }^{25}$ Stanisław Litak (1932-2010) - kierownik Katedry Dydaktyki Historii i Historii Szkolnictwa na Wydziale Nauk Humanistycznych oraz Katedry Historii Wychowania i Myśli Pedagogicznej na Wydziale Nauk Społecznych KUL; badacz historii Kościoła, wychowania i szkolnictwa (biogram: M. Surdacki, Profesor Stanisław Litak - historyk Kościoła, wychowania i szkolnictwa, w: Religie, edukacja, kultura. Księa pamiatkowa dedykowana Profesorowi Stanisławowi Litakowi, red. M. Surdacki, Lublin 2002 s. 5-14).

${ }^{26}$ Wiktoria Śliwowska - ur. 1931 pracownik Instytutu Historii PAN, badaczka dziejów Rosji i losów polskich zesłańców na Syberię (notka biograficzna na okładce: W. Śliwowska, Ucieczki z Sybiru, Warszawa 2005).

${ }^{27}$ Stefan Mizera (1924-2002) - kapłan archidiecezji częstochowskiej. W latach 1987-2002 sprawował funkcję dyrektora Archiwum Diecezjalnego w Częstochowie (nekrolog oprac. przez ks. Jana Związka, w: www.archidiecezjaczestochowska.pl dostęp: 12. 10. 2015 r.) 
Wykres nr 2. Woluminy zakupione i darowane Bibliotece Instytutu Historii KUL w latach 1971-2011/ The volumes purchased and donated to the Library of the Institute of History of KUL in the years 1971-2011



* Dane za rok 2005-2011 obejmują rok akademicki.

W świetle danych, aż 74,7\% księgozbioru zgromadzonego w latach 19712011 pochodzi z zakupu. Trzeba podkreślić, że wśród woluminów pozyskiwanych w ten sposób, znajdują się książki kupowane z funduszy badań własnych pracowników Instytutu Historii.

Wiele książek skrywa ekslibrisy bądź dedykacje bardziej lub mniej znanych osobistości m.in.: hr. Jerzego Moszyńskiego ${ }^{28}$, Roberta Przegalińskiego ${ }^{29}$, Tadeusza Rojowskiego ${ }^{30}$, Jerzego Grobickiego ${ }^{31}$, Wincentego Zakrzewskiego ${ }^{32}$, Ada-

${ }^{28}$ Jerzy Moszyński (1847-1924) - publicysta krakowski. Zob. W. Cabaj, Darowizna Jerzego Moszyńskiego dla Biblioteki Katolickiego Uniwersytetu Lubelskiego, „Teka Komisji Historycznej PAN", 2 (2005) s. 42-72.

${ }^{29}$ Robert Przegaliński (1840-1927) - prawnik, literat, regionalista. Zob. F. Rymarz, Przegaliński Robert Alfred, w: Stownik biograficzny adwokatów polskich, t. 2, Warszawa 2007, s. 425-426.

${ }^{30}$ Tadeusz Rojowski (1856-1938) - ziemianin, działacz społeczny. Był delegatem Towarzystwa Kredytowego Ziemskiego ds. szacowania majątków. W 1915 r. organizował w Lublinie Milicję Obywatelska, uczestniczył w pracach nad przygotowaniem reformy rolnej. W 1929 r. został odznaczony krzyżem Polonia Restituta. Wspierał finansowo KUL oraz był skarbnikiem Komitetu Towarzystwa Biblioteki im. Hieronima Łopacińskiego. Zob. T. Radzik, Rojowski Tadeusz, w: Stownik biograficzny miasta Lublina. t. 2, red. T. Radzik, A. Witusik, J. Ziółek, Lublin 1996, s. 212-213.

31 Jerzy Grobicki (1891-1972) - dowódca 1 Pułku Szwoleżerów Józefa Piłsudskiego w Warszawie 15.VIII.1920 - 8.V. 1921; oficer Dowództwa Wojska Polskiego na Środkowym Wschodzie I - IV. 1942; oficer Dowództwa Armii Polskiej na Wschodzie III-XII 1943. Zob. M. Koral, Biogram ptk dypl. Jerzego Grobickiego zmarłego 22 września 1972 r. w Toronto, „Wojskowy Przegląd Historyczny", 63 (1972) nr 4, s. 358.

${ }^{32}$ Wincenty Zakrzewski (1844-1918) - historyk, badacz dziejów powszechnych i Polski w XVI w., edytor źródeł. W latach 1871-1909 związany z Uniwersytetem Jagiellońskim. Zob. M. Wierzbicka, Wincenty Zakrzewski, w: Słownik historyków polskich, red. M. Prosińska-Jack1, Warszawa 1994, s. 572. 
ma Skałkowskiego ${ }^{33}$, Ignacego Baranowskiego ${ }^{34}$. Na wielu kartach pojawiają się znaki własnościowe wykładowców naszej Alma Mater takich jak: Stanisław Ptaszycki $^{35}$, Leon Białkowski ${ }^{36}$, Stanisław Smolka ${ }^{37}$, Mieczysław Popławski ${ }^{38}$, Zygmunt Kukulski ${ }^{39}$, ks. Cezary Pęcherski ${ }^{40}$.

\section{Baza lokalowa}

W dniu 8 stycznia 1922 r. nastąpiło otwarcie wschodniego skrzydła tzw. starego gmachu KUL, w którym na parterze obecnie znajduje się siedziba biblioteki.

${ }^{33}$ Adam Skałkowski (1877-1951) - znawca problematyki legionowo-napoleońskiej, wydawca źródeł z przełomu XVIII i XIX w. Pozostawił ok. 300 publikacji naukowych. Wykładał historię nowożytną na Uniwersytecie Poznańskim. Był członkiem Polskiej Akademii Umiejętności oraz wielu towarzystw m.in. Poznańskiego Towarzystwa Przyjaciół Nauk. Zob. K. Olejnik, Adam Skałkowski, w: Wybitni historycy wielkopolski, red. J. Strzelczyk, Poznań 2010, s. 258-243.

${ }^{34}$ Baranowski Ignacy Tadeusz (1879-1917) - absolwent wydziału historyczno-filozoficznego uniwersytetu w Moskwie. Doktorat i habilitację uzyskał na Uniwersytecie Jagiellońskim. Pracował jako archiwista w warszawskim Archiwum Skarbowym oraz pełnił funkcję dyrektora Biblioteki Ordynacji Krasińskich w Warszawie. Wydał wiele źródeł do dziejów wsi polskiej. Jego badania koncentrowały się na historii gospodarczej i społecznej. Zob. K. Tymieniecki, Baranowski Ignacy Kazimierz, w: Polski Stownik Biograficzny, t. 1, Kraków 1935, s. 279-280.

35 Stanisław Ptaszycki (1853-1933) - wykładał nauki pomocnicze historii i historię średniowieczną na KUL (1918-1926). Sprawował funkcję wicerektora KUL w roku akademickim 1921/1922. Był pierwszym dyrektorem Biblioteki Uniwersyteckiej oraz Archiwum Państwowego w Lublinie. W latach 1926-1932 pracował w Ministerstwie Wyznań Religijnych i Oświecenia Publicznego jako naczelny dyrektor Wydziału Archiwów Państwowych. Zob. G. Karolewicz, Nauczyciele akademiccy Katolickiego Uniwersytetu Lubelskiego w okresie międzywojennym, t. 2, Lublin 1994, s. $182-185$.

${ }^{36}$ Leon Białkowski (1885-1952) - w latach 1926-1928 prowadził zajęcia z nauk pomocniczych historii i historii średniowiecznej na KUL. Od 1933 r. do 1938 r. piastował funkcję prorektora KUL. Zob. Karolewicz, Nauczyciele akademiccy, s. 17-19.

${ }^{37}$ Stanisław Smolka (1854-1924) - wybitny historyk; związany z Uniwersytetem we Lwowie, Uniwersytetem Jagiellońskim (pełnił w latach 1895-1896 funkcję rektora) oraz w latach 1919-1924 z Uniwersytetem Lubelskim. Zob. Karolewicz, Nauczyciele akademiccy, s. 198-199.

${ }^{38}$ Mieczysław Popławski (1893-1946) - filolog klasyczny. W 1933/1934 r. dziekan, a w 1934/1935 r. prodziekan WNH. Współzałożyciel Towarzystwa Naukowego KUL, współpracownik Komisji Filologicznej PAU, prezes Towarzystwa Biblioteki Publicznej im. H. Łopacińskiego. Zob. Karolewicz, Nauczyciele akademiccy, s. 176

${ }^{39}$ Zygmunt Kukulski (1890-1944) - pedagog i historyk. W latach 1920-1939 wykładał pedagogikę na KUL. W tym samym czasie nauczał literaturę polską i historię w Państwowym Gimnazjum im. S. Staszica. W latach 1927-1930 był dziekanem WNH KUL. Zob. Karolewicz, Nauczyciele akademiccy, s. 116-118.

${ }^{40}$ Cezary Pęcherski (1881-1925) - duchowny katolicki, w latach 1918-1925 wykładowca historii literatury staropolskiej oraz nauki dykcji na WNH i Wydziale Teologicznym KUL. Założyciel i prezes Lubelskiego Oddziału Towarzystwa Literackiego im. Adama Mickiewicza. Zob. Karolewicz, Nauczyciele akademiccy, s. 169-171. 
Źródła podają, że w 1928 r. mieściła się wspólnie z biblioteką Seminarium Historii Kościoła w sali nr 12. Sala posiadała jedną szafę i siedem półek ${ }^{41}$.

W świetle danych z kwestionariusza za $1950 \mathrm{r}$. biblioteka posiadała cztery pomieszczenia (łącznie z magazynami). W Zakładzie wydzielone były dwie pracownie: seminarium średniowiecznego oraz starożytnego i nowożytnego przeznaczone dla magistrantów. Studenci młodszych lat mieli pracować w dwóch czytelniach - na jedną z nich zaadaptowano korytarz i w tej wg regulaminu „można było rozmawiać szeptem" ${ }^{\prime 2}$. Liczba miejsc w czytelni wynosiła $80^{43}$. Ogólna powierzchnia zajmowanych pomieszczeń liczyła $98,80 \mathrm{~m}^{244}$. W roku akademickim 1953/1954 próbowano ulepszyć warunki lokalowe poprzez reperację podłogi i wstawienie dodatkowego pieca ${ }^{45}$. W styczniu 1968 r. rozpoczęto kolejny remont czytelni ze względu na zagrzybienie lokalu. Zakończenie prac przewidywano dopiero z początkiem nowego roku akademickiego ${ }^{46}$. Systematyczny napływ książek do biblioteki powodował, że brakowało miejsca na nowe woluminy. W związku z tym istniała konieczność znalezienia nowych pomieszczeń magazynowych. W latach 70-tych XX w., podczas sprawowania funkcji bibliotekarza przez mgr Stanisława Olczaka, przeprowadzono remont, w wyniku którego przebito strop podłogi ze znajdującymi się pod nią piwnicami. Wówczas zaadaptowano piwnice na magazyny biblioteczne ${ }^{47}$. W 1998 r. biblioteka otrzymała kolejne piwnice, zajmowane dotąd przez Archiwum Uniwersyteckie KUL.

W latach 2000-2007 w bibliotece funkcjonowały dwie czytelnie (sala 20 i 28). W okresie wakacyjnym w 2006 r. dokonano renowacji szaf z tzw. starej czytelni, w których przechowywano księgozbiór podręczny. Drugie lektorium (obecnie Muzeum Uniwersyteckie) zostało wyposażone w komputery i nowe szafy. Modernizacji tej patronował ówczesny dyrektor Instytutu Historii prof. Henryk Wąsowicz. W trakcie przerwy semestralnej (luty-marzec) w 2007 roku w magazynie zostały wymienione drewniane regały na metalowe (około $80 \%$ regałów). Podczas tego remontu, biblioteka otrzymała specjalne regały na mapy (wykonane w stolarni uniwersyteckiej). W związku z przeniesieniem, w roku akademicki 2007/2008, większości katedr Instytutu Historii do nowego gmachu Collegium Norwidianum, dawne lektorium zostało powiększone o kolejne pomieszczenia

${ }^{41}$ AU KUL, Biblioteka Uniwersytecka, Sprawozdania kierowników bibliotek seminaryjnych 1922-1939; Pismo Kierownika Seminarium Historycznego prof. Aleksandra Kossowskiego do Dziekana WNH z dnia 18.05.1928 r.

${ }^{42}$ AU KUL, Wydział Nauk Humanistycznych. Zakład Historii. Stan księgozbioru 1948-1955; Regulamin Zakładu Historii KUL z dnia 19.11.1954 r.

${ }^{43}$ AU KUL, Wydział Nauk Humanistycznych. Zakład Historii. Stan księgozbioru 1948-1955; Kwestionariusz statystyczno-sprawozdawczy za $1950 \mathrm{r}$.

${ }^{44}$ AU KUL, Wydział Nauk Humanistycznych. Zakład Historii. Stan księgozbioru 1948-1955; Kwestionariusz statystyczno-sprawozdawczy za 1950 rok. Sygn.V 421

${ }^{45}$ AU KUL, Wydział Nauk Humanistycznych. Zakład Historii; Pismo do Dziekana WNH z dn. 25.06.1954 r.

${ }^{46}$ AU KUL, Wydział Nauk Humanistycznych. Zakład Historii. Sygn.V 421; Protokół wizji lokalnej w Zakładzie Historii z dnia 17 stycznia 1968 r.

${ }^{47}$ Relacja ustna prof. Stanisława Olczaka z dn. 26.07.2012 r. (w zbiorach A. Pawłowskiej). 
(sale nr: 22 i 24). Powierzchnia pomieszczeń bibliotecznych (w tym magazynowych) wzrosła do $247 \mathrm{~m}^{2}$. Obecnie czytelnia liczy 52 miejsca i jest wyposażona w 11 stanowisk komputerowych.

\section{Prace prowadzone $w$ bibliotece}

Od momentu zatrudnienia w bibliotece etatowego bibliotekarza, odpowiedzialność za księgozbiór spoczywała na jednej osobie. Stałe godziny pracy bibliotekarza, sąsiadowanie z katedrami sprawiły, że biblioteka stała się centrum życia Instytutu Historii. Mgr Elżbieta Janicka-Olczak pełniła także funkcję sekretarza Sekcji (Instytutu) Historii. Zmieniło się to w 2000 r. wraz z utworzeniem samodzielnego sekretariatu w Instytucie Historii ${ }^{48 .}$

Obecnie działania bibliotekarzy pracujących w Bibliotece Instytutu Historii koncentrują się na gromadzeniu, opracowywaniu i udostępnianiu księgozbioru. Ponadto organizują oni szkolenia z przysposobienia bibliotecznego dla studentów pierwszego roku historii oraz krajoznawstwa i turystyki wielokulturowej. Od 2006 r. rozpoczęto wprowadzanie książek do komputerowego systemu VIRTUA. Do 05. 07. 2012 r. opracowano 17.785 rekordów bibliograficznych. Od kilku lat poszerza się grono korzystających z zasobów biblioteki. Wiąże się to z faktem, że coraz większą popularnością cieszą się studia o charakterze międzywydziałowym. Przybywają nowe interdyscyplinarne kierunki, w tym także - utworzony w 2012 r. w Instytucie Historii - nowy kierunek krajoznawstwo i turystyka kulturowa.

Słowa kluczowe: Biblioteka Instytutu Historii Katolickiego Uniwersytetu Lubelskiego Jana Pawła II, Biblioteka Zakładu Historii Kultury, księgozbiór, czytelnicy, darowizny, ekslibris, Elżbieta Janicka-Olczak, prof. Stanisław Olczak

\section{BIBLIOGRAFIA}

\section{Żródła}

Archiwum Uniwersyteckie Katolickiego Uniwersytetu Lubelskiego Jana Pawła II

- Biblioteka Uniwersytecka, Sprawozdania kierowników bibliotek seminaryjnych 19221939.

- Kancelaria Rektorska.

- Kancelaria Rektorska. Biblioteka Uniwersytecka 1952-1969.

- Kancelaria Rektorska. Biblioteka Uniwersytecka. Korespondencja. Sprawy ogólne 1969-1984.

- Kancelaria Rektorska. Biblioteki Zakładowe 19461950.

- Księga Protokołów Rady Wydziału Nauk Humanistycznych. skiej).

${ }^{48}$ Relacja ustna mgr Elżbiety Janickiej-Olczak z dn. 26. 07. 2012 r. (w zbiorach A. Pawłow- 
- Referat Personalny, Akta osobowe pracowników.

- Senacka Komisja Młodzieżowo-Stypendialna. Studenckie Stypendia Socjalne. Stypendia naukowo-zakładowe 1994-1995.

- Wydział Nauk Humanistycznych. Zakład Historii.

Regulamin Biblioteki Uniwersyteckiej Katolickiego Uniwersytetu Lubelskiego Jana Pawła II z 25 kwietnia $2007 \mathrm{r}$.

Statut Katolickiego Uniwersytetu Lubelskiego Jana Pawła II z dnia 17 marca 2006 r.

\section{Opracowania}

Bender R., Historia na Wydziale Nauk Humanistycznych KUL (1918-1966), „Roczniki Humanistyczne", 18 (1970) z. 2, s. 141-159.

Brus A., Filipowicz M., Niebelski E., Profesor Wiktoria Śliwowska, w: Zesłańcy postyczniowi w Imperium Rosyjskim. Studia dedykowane Profesor Wiktorii Śliwowskiej, red. E. Niebelski, Lublin-Warszawa 2008, s. 9-12.

Cabaj W., Darowizna Jerzego Moszyńskiego dla Biblioteki Katolickiego Uniwersytetu Lubelskiego, „Teka Komisji Historycznej PAN”, 2 (2005) s. 42-72.

Karolewicz G., Nauczyciele akademiccy Katolickiego Uniwersytetu Lubelskiego w okresie międzywojennym, t. 2, Lublin 1994.

Koło Naukowe Historyków Studentów KUL 1919-2004 - księga jubileuszowa, pod red. E. M. Ziółek, Lublin 2004.

Koral M., Biogram plk dypl. Jerzego Grobickiego zmarłego 22 września 1972 r. w Toronto, „Wojskowy Przegląd Historyczny”, 63 (1972) nr 4, s. 35.

Koszałka B., Biblioteki zakładowe Katolickiego Uniwersytetu Lubelskiego, „Archiwa Biblioteki i Muzea Kościelne”, 23 (1971) s. 179-197.

Olejnik K., Adam Skałkowski, w: Wybitni historycy wielkopolscy, red. J. Strzelczyk, Poznań 2010, s. 243-258.

Radzik T., Rojowski Tadeusz, w: Słownik biograficzny miasta Lublina t. 2, red. T. Radzika, A. Witusik, J. Ziółek, Lublin 1996, s. 212-213.

Rymarz F., Przegaliński Robert Alfred, w: Słownik biograficzny adwokatów polskich, t. 2, Warszawa 2007, s. 425-426.

Skład osobowy. Spis wykładów i instytucji Katolickiego Uniwersytetu Lubelskiego w roku akademickim 1946/1947 oraz sprawozdania za lata ubiegłe, Lublin 1947.

Surdacki M., Profesor Stanisław Litak - historyk Kościoła, wychowania i szkolnictwa, w: Religie, edukacja, kultura. Księga pamiątkowa dedykowana Profesorowi Stanisławowi Litakowi, pod red. M. Surdackiego, Lublin 2002 s. 5-14.

Tymieniecki K., Baranowski Ignacy Kazimierz, w: Polski Słownik Biograficzny t. 1, Kraków 1935, s. 279-280.

Wierzbicka M., Wincenty Zakrzewski, w: Słownik historyków polskich, Warszawa 1994, s. 572.

Wojtiszek J, Wspomnienia z lat studiów, w: Katolicki Uniwersytet Lubelski w latach 1925-1939 we wspomnieniach swoich pracowników i studentów, wstęp i red. Grażyna Karolewicz, Lublin 1989, s. 244-249.

Wyszyński S., Kazanie i przemówienie na uroczystości milenijne na KUL-u, „Zeszyty Naukowe Katolickiego Uniwersytetu Lubelskiego”, R. 9 (1966), nr 4, s. 63-81 
THE LIBRARY OF THE INSTITUTE OF HISTORY OF THE JOHN PAUL II CATHOLIC UNIVERSITY OF LUBLIN

\begin{abstract}
Summary
The Library of the Institute of History of the John Paul II Catholic University of Lublin collects, describes and lends books, magazines, maps from such fields as history, archaeology, archive, art history, cartography, tourism. According to historical sources, the library was established in 1918 or 1919. Initially, the library was named the Library of the Historical Seminar. The size of the collection increased both through purchase and through donations. The books were donated, among others, by prof. Zygmunt Sułowski, prof. Stanisław Litak, prof. Wictoria Śliwowska, Rev. Dr Stefan Mizera. The Library was run successively by Stanisław Olczak and Elżbieta Janicka-Olczak.
\end{abstract}

Keywords: The Library of the Institute of History of the John Paul II Catholic University of Lublin, the Library of the Institute of the History of Culture, book collection, readers, donations, ex-libris, Elżbieta Janicka-Olczak, prof. Stanisław Olczak 